\title{
Production and Some Properties of Crude Alkaline Proteases of Indigenous Central Amazonian Rhizobia Strains
}

\author{
Arlem Nascimento de Oliveira ${ }^{*}$, Luiz Antonio de Oliveira ${ }^{1}$ and Jerusa Souza Andrade ${ }^{2}$ \\ ${ }^{I}$ Departamento de Ciências Agronômicas; Instituto Nacional de Pesquisas da Amazônia; Av. André Araújo, 2936; \\ C. P.: 478; 69060-001; Manaus - AM - Brasil. ${ }^{2}$ Departamento de Tecnologia de Alimentos; Instituto Nacional de \\ Pesquisas da Amazônia; Av. André Araújo, 2936; C. P.: 478; 69060-001; Manaus - AM - Brasil
}

\begin{abstract}
Two rhizobia strains isolated from soils of the Central Amazonian floodplain produced appreciable quantities of crude alkaline protease extracts with inexpensive carbon and nitrogen sources. These protease crude extracts were optimally active at $\mathrm{pH}$ 9.0-11.0. The optimum temperatures were $35{ }^{\circ} \mathrm{C}$ for Rhizobium sp. strain $\mathrm{R}-986$ and $55^{\circ} \mathrm{C}$ for Bradyrhizobium sp. strain R-993. Protease activities in the crude extracts were enhanced in the presence of 5 $\mathrm{mM}$ metal ions, such as $\mathrm{Na}^{+}, \mathrm{Ca}^{2+}, \mathrm{Mg}^{2+}$ and $\mathrm{Mn}^{2+}$. Rhizobia proteases were strongly inhibited by PMSF, a serineprotease inhibitor. The enzymes were active in the presence of surfactants (SDS and Triton X-100) and stable in oxidizing $\left(\mathrm{H}_{2} \mathrm{O}_{2}\right)$ and reducing agents ( $\beta$-mercaptoethanol), and organic solvents (acetone, hexane, methanol, 1 propanol and toluene).
\end{abstract}

Key words: Rhizobium, Bradyrhizobium, enzymatic activities, organic surfactants

\section{INTRODUCTION}

Proteases [serine protease (EC. 3.4.21), cysteine (thiol) protease (EC. 3.4.22), aspartic protease (EC. 3.4.23) and metalo-protease (EC. 3.4.24)] are the most important class of enzymes that catalyze total hydrolysis of protein, and have been studied extensively since the advent of enzymology. Proteases from the microbial sources are preferred to enzymes from plant and animal sources, since they possess almost all the characteristics desired for the biotechnological applications (Gupta et al., 2002). Bacterial alkaline proteases are of particular interest due to their numerous applications in the detergent, tanning, chemical and dairy industries.
Furthermore, they are used in pharmaceuticals and medical diagnosis, recovery of silver from X-ray films, etc. (Gupta et al., 2002; Joo et al., 2003).

At present, Bacillus (Gupta et al., 2002; Nilegaonkar et al., 2007), Pseudomonas (Ogino et al., 2001; Rahman et al., 2005), Aspergillus (Tunga et al., 2003), Streptomyces (Azeredo et al., 2004) and Penicillium (Agrawal et al., 2004) species are considered to be the most important sources of industrial proteases. Nevertheless, various other sources of microbial proteases are being investigated (Elibol and Moreira, 2005; Seeta Laxman et al., 2005; Vidyasagar et al., 2006).

While alkaline proteases from several bacteria

*Author for correspondence: arlem@inpa.gov.br 
have been extensively characterized, similar attention has not been paid to rhizobia bacteria. Rhizobia are widespread soil bacteria able to induce the formation of root nodules and to fix the atmospheric nitrogen in the cultivated and wild legumes. To date, symbiotic biological fixation is the most important topic of investigation involving these soil bacteria. However, the ability to produce a variety of other enzymes may be an attractive characteristic in these beneficial microorganisms (Oliveira, 2006). In previous studies (Oliveira et al., 2006a,b), several indigenous strains of rhizobia from Central Amazonia as promising sources of industrially relevant enzymes for biotechnological uses have been reported. On solid medium, some of these stains were able to grow and produce appreciable amounts of extracellular proteases at $\mathrm{pH} 8.0$ (Oliveira et al., 2006a), indicating the probable alkaline nature of these rhizobia proteases. However, these extracellular enzymes have not been characterized yet. This paper reports the production of crude alkaline protease extracts from two rhizobia strains and provides some information on their physiochemical properties.

\section{MATERIALS AND METHODS}

\section{Bacteria strains and culture conditions}

The rhizobia used in this study were isolated from the soils of the Central Amazonian floodplain naturally rich in nutrients and low in acidity. The two rhizobia strains were previously identified at the Center for Nuclear Energy and Agriculture (CENA, Piracicaba, SP, Brazil). Based on 16S rRNA sequence comparison, strain INPA R-986 was identified as Rhizobium sp. (99\% homology), and INPA R-993 as Bradyrhizobium sp. (99\% homology) (Oliveira, 2006). The R-986 and R-993 strains are deposited in the culture collection of the National Institute for Amazonian Research INPA, Manaus, AM, Brazil.

Stock cultures were maintained on yeast extractmannitol agar (YMA) slants (Vincent, 1970) at 4 ${ }^{\circ} \mathrm{C}$. Based on a previous study (Oliveira, 2006), two simple and inexpensive media for protease production were used. For strain INPA R-986, the medium was composed of $\left(\mathrm{g} \mathrm{L}^{-1}\right): 10.0$ gelatine, $0.4 \mathrm{~K}_{2} \mathrm{HPO}_{4}, 0.1 \mathrm{~K}_{2} \mathrm{HPO}_{4}, 0.2 \mathrm{MgSO}_{4} .7 \mathrm{H}_{2} \mathrm{O}$ and $0.1 \mathrm{NaCl}$. For strain INPA R-993, the gelatine was replaced by soybean flour. The $\mathrm{pH}$ of the media were adjusted to 6.8 with $\mathrm{KOH}$ and autoclaved at $120{ }^{\circ} \mathrm{C}$ for $20 \mathrm{~min}$. Fifty milliliters medium was placed in $150 \mathrm{~mL}$ Erlenmeyer flasks and inoculated with $1 \mathrm{~mL}$ of standardized inoculum culture $\left(2.4 \times 10^{9} \mathrm{CFU}\right)$, grown in liquid $\mathrm{YM}$ medium (Vincent, 1970) and incubated at $28{ }^{\circ} \mathrm{C}$ with rotary shaking of 65 cycles $\mathrm{min}^{-1}$. Cultures were harvested and centrifuged $(12000 \mathrm{rpm}, 10$ min) at $24 \mathrm{~h}$ intervals during 8 (R-986) and 11 (R993) days of growth. At these intervals, the cellfree culture supernatant thus obtained served as the crude enzyme source to evaluate the protease activity, total extracellular protein and $\mathrm{pH}$ of the medium. Biomass production $\left(\mathrm{g} \mathrm{L}^{-1}\right)$ was determined by drying the cell mass at $105{ }^{\circ} \mathrm{C}$ until constant weight.

\section{Assay of protease activity}

Protease activity was determined according to the modified method of Olajuyigbe and Ajele (2005). The reaction mixture in a total volume of $600 \mu \mathrm{L}$ was composed of $1 \%(w / v)$ azocasein (SigmaAldrich, St. Louis, Mo., U.S.A) solution in Tris$\mathrm{HCl}$ buffer $(50 \mathrm{mM}, \mathrm{pH} 7.0)$ and appropriately diluted enzyme crude extract. After $60 \mathrm{~min}$ incubation at $37{ }^{\circ} \mathrm{C}$ in a water bath, the reaction was terminated by the addition of $500 \mu \mathrm{L}$ of $15 \%$ $(\mathrm{w} / \mathrm{v})$ trichloroacetic acid (TCA). After the separation of the un-reacted azocasein precipitate by centrifugation, $1000 \mu \mathrm{L}$ of clear supernatant was mixed with equal volume of $1.0 \mathrm{M} \mathrm{NaOH}$. Absorbance was read at $440 \mathrm{~nm}$ using a Spectrum UV-Vis Spectrophotometer and appropriate blanks were included. One unit (U) enzyme activity was defined as the amount of crude enzyme required to produce an increase in absorbance equal to 1.0 in 60 min under experimental conditions.

\section{Protein assay}

Total extracellular protein secretion was estimated by the biuret method (Gornall et al., 1949), using bovine serum albumin as the standard.

\section{Properties of the crude enzymes}

The protease crude extracts obtained after cell growth for seven (INPA R-986) and eight (INPA R-993) days were used for characterization assays.

\section{Influence of pH on enzyme activity and stability} The protease activity in the crude extract was measured at different $\mathrm{pH}$ values. The $\mathrm{pH}$ was adjusted using the following buffers $(50 \mathrm{mM})$ : citrate phosphate $(\mathrm{pH} 5.0-6.0)$, phosphate $(\mathrm{pH} 7.0-$ 8.0), Tris- $\mathrm{HCl}(9.0-10.0)$ and glycine $\mathrm{NaOH}$ (11.0- 
12.0). Reaction mixtures were incubated for 30 min at $37{ }^{\circ} \mathrm{C}$ and the activity was measured as in the standard assay above. The $\mathrm{pH}$ stability was determined by pre-incubating the crude enzyme extracts in different buffers ( $\mathrm{pH} 5.0-12.0)$ for $24 \mathrm{~h}$ at $37^{\circ} \mathrm{C}$.

\section{Influence of temperature on enzyme activity and stability}

The activity of the crude protease extract was determined by incubating the reaction mixture at different temperatures, ranging from 25 to $80{ }^{\circ} \mathrm{C}$, for $30 \mathrm{~min}$ in a $50 \mathrm{mM}$ Tris- $\mathrm{HCl}(\mathrm{pH} \mathrm{10.0)}$. To determine the enzyme stability with changes in temperature, crude protease extract was preincubated for $2 \mathrm{~h}$ at $25-80{ }^{\circ} \mathrm{C}$. After incubation, residual enzymatic activity was determined under the standard assay conditions.

\section{Influence of metal ions on enzyme activity}

The effects of $\mathrm{K}^{+}, \mathrm{Na}^{+}, \mathrm{Ca}^{2+}, \mathrm{Hg}^{2+}, \mathrm{Mg}^{2+}, \mathrm{Mn}^{2+}$ and $\mathrm{Zn}^{2+}$ ions on crude protease extract were investigated by adding these cations to the reaction mixture to final concentrations of 1 and $5 \mathrm{mM}$. Relative enzyme activities were measured under the optimum conditions of both $\mathrm{pH}$ and temperature as required by each rhizobia protease.

\section{Influence of surfactants on enzyme activity}

The enzyme activity against different surfactants (Triton X-100, Sodium Dodecyl Sulfate (SDS) and Tween 80 ) in reaction mixture was determined by assaying the crude enzyme in the presence of 1 and $2 \%$ of each surfactant at $37^{\circ} \mathrm{C}$ for $60 \mathrm{~min}$. Protease activity was determined as described previously.

\section{Influence of inhibitors on enzyme activity}

The assay procedure was the same as described above, except that the reaction mixture included $\beta$ mercaptoethanol and $\mathrm{HgCl}_{2}$ (cysteine protease inhibitors), Ethylene Diamine Tetraacetic Acid (EDTA, metalloprotease inhibitor), and p-Methyl Sulphonyl Fluoride (PMSF, serine protease inhibitor) at final concentrations of 5,10 and 100 $\mathrm{mM}$. Protease activity was determined as described previously.

Influence of oxidizing and reducing agents on enzyme activity

The crude protease extracts were incubated with $\mathrm{H}_{2} \mathrm{O}_{2}$ (oxidizing agent) and $\beta$-mercaptoethanol (reducing agent) at concentrations of 5 and $10 \mathrm{mM}$ for $30 \mathrm{~min}$ at $37{ }^{\circ} \mathrm{C}$. After incubation, protease activity was determined as described previously.

\section{Influence of organic solvent on enzyme activity} The crude enzymes were incubated at $37{ }^{\circ} \mathrm{C}$ for 30 min with two different concentrations (10 and $20 \%$ ) of acetone, n-hexane, methanol, 1-propanol and toluene. Proteolytic activity without organic solvent was considered to be $100 \%$.

\section{Experimental design and statistical analyses}

All the experiments were organized using a completely randomized design with three replicates, repeated twice for reproducibility. The analysis of variance was carried out using the Statistica 7.0 software package (StaSoft, Inc., Tulsa, OK). Pearson's correlation coefficients also were considered significant if $p<0.05$. The standard error in results of all assays was lower than $5 \%$.

\section{RESULTS AND DISCUSSION}

\section{Growth curve and protease production}

Rhizobium sp. strain INPA R-986 and Bradyrhizobium sp. strain INPA R-993 showed maximal biomass production on the $4^{\text {th }}$ and $6^{\text {th }}$ days of cultivation, respectively (Figs 1, A and B). This result could be explained by the fact that the isolate of Rhizobium present a fast growth rate, while Bradyrhizobium a slow growth rate as referenced in Oliveira (2006). Strain INPA R-986 exhibited maximum total extracellular protein on the $4^{\text {th }}$ day of incubation, whereas the strain INPA R-993 reached its maximum on the $3^{\text {nd }}$ day of cultivation (data not shown).

Both rhizobia strains exhibited maximal protease activities when the cell growth reached the stationary phase (Figs 1, A and B). Similar results have been documented for other bacterial proteases (Sánchez-Porro et al., 2003; Patel et al., 2005; Nilegaonkar et al., 2007). A comparison among the strains showed that the enzyme activity of strain INPA R-993 (88 $\left.\mathrm{U} \mathrm{mL}^{-1}\right)$ was about sixfold higher than the activity of strain INPA R-986 $\left(15 \mathrm{U} \mathrm{mL}^{-1}\right)$. There was a slight drop in $\mathrm{pH}$ from 6.8 to 6.3 during the first $24 \mathrm{~h}$ growth of the strain INPA R-986. This could be attributed to the production of acids during the bacterial growth. Then, the $\mathrm{pH}$ of the culture medium increased to 7.3 after 8 days incubation (Fig. 1A). Similarly, 
the $\mathrm{pH}$ of the culture medium of Bradyrhizobium strain increased from 6.8 to 8.4 after 10 days growth (Fig. 1B). The rise of $\mathrm{pH}$ could be due to the utilization of organic acids or production of alkaline compounds, as suggested by Rahman et al. (2005).

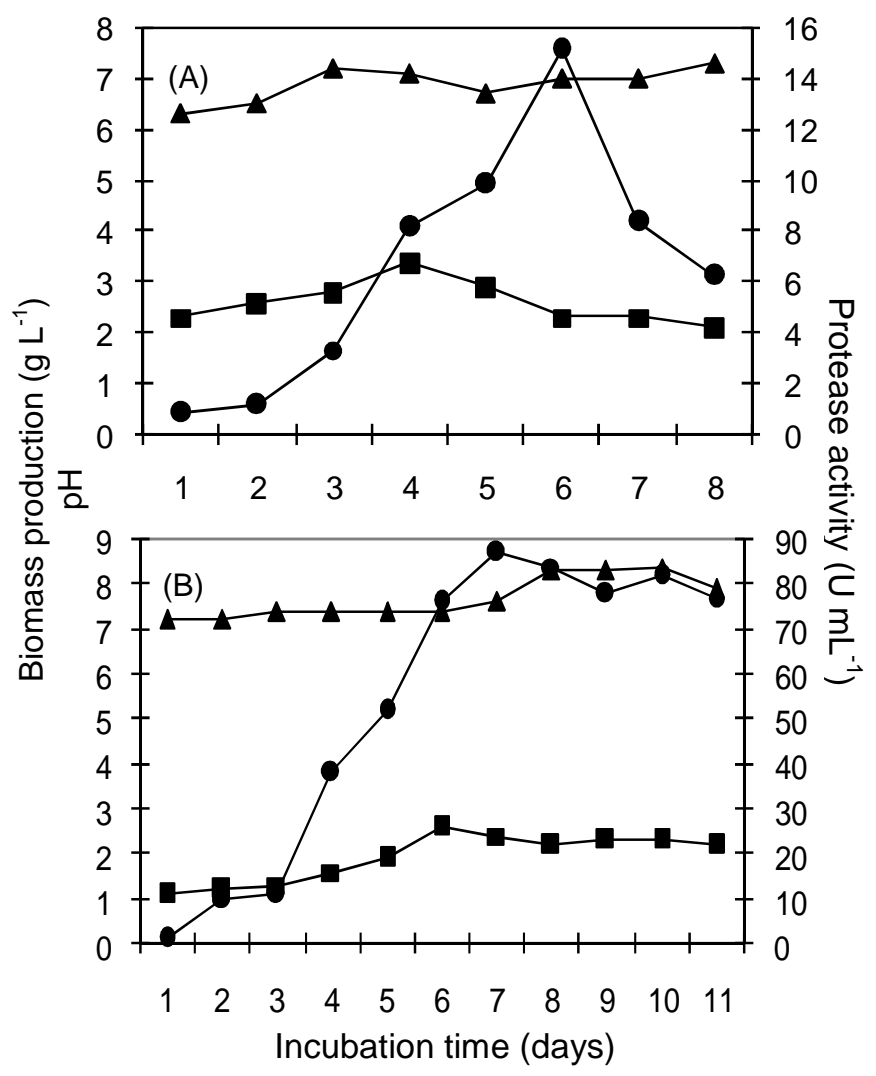

Figure 1 - Biomass production $(\boldsymbol{\bullet})$, pH variation $(\boldsymbol{\Lambda})$ and enzyme activities $(\bullet)$ of strains R-986 (A) e R-993 (B) at different incubation times.

\section{Correlations among the parameters evaluated}

For both rhizobia strains, there were significant and positive correlations between the proteolytic activity and $\mathrm{pH}$ of the culture medium. This interdependence was more prominent for the strain $\mathrm{R}-993(\mathrm{r}=0.75 ; \mathrm{p}<0.001 ; \mathrm{n}=33)$ than for the strain R-986 ( $\mathrm{r}=0.47 ; \mathrm{p}<0.021 ; \mathrm{n}=24)$, suggesting that the protease produced by the Bradyrhizobium was relatively more tolerant to an alkaline environment. Similar relationships have been registered for proteases from Nocardiopsis sp. (Moreira et al., 2003), Bacillus licheniformis (Al-Shehri et al., 2004), Teredinobacter turnirae (Elibol and Moreira, 2005), Conidiobolus coronatus (Seeta Laxman et al., 2005) and Bacillus sp. (Genckal and Tari, 2006). Protease activity and biomass production were also closely associated for both rhizobia strains (for the R-993, $\mathrm{r}=0.97 ; \mathrm{p}<0.001 ; \mathrm{n}=33$, and for the R-986, $\mathrm{r}=$ $0.62 ; \mathrm{p}<0.002 ; \mathrm{n}=24$ ), confirming other studies with Pseudomonas fluorescens $22 \mathrm{~F}$ (Schokker and van Boekel, 1997), Bacillus sp. (Nascimento et al., 2004) and $P$. aeruginosa strain $\mathrm{K}$ (Rahman et al., 2005). Protease production from the Bradyrhizobium strain was negatively correlated $(\mathrm{r}=-0.52 ; \mathrm{p}<0.003 ; \mathrm{n}=33)$ to the total extracellular protein, indicating the presence of more than one type of protease in the crude enzymatic extract. Similar findings were reported for crude enzyme preparations from Nocardiopsis sp. (Moreira et al., 2003) and Streptomyces sp. (Azeredo, 2004).

Influence of pH on enzyme activity and stability The crude protease of the Rhizobium strain R-986 was active between $\mathrm{pH} 6.0$ and 11.0, with an 
optimum between $\mathrm{pH}$ 10.0-11.0 (Fig. 2). The optimum $\mathrm{pH}$ for protease activity from strain R993 was between 9.0-10.0, but significant levels of activity (above 70\%) were still detected at $\mathrm{pH} 8.0$ and 11.0 (Fig. 2).

Optimum $\mathrm{pH}$ between 9.0 and 11.0 has been reported for alkaline proteases from Bacillus spp. (Al-Shehri et al., 2004; Patel et al., 2005; Genckal and Tari, 2006) and Pseudomonas spp. (Schokker and van Boekel, 1997; Najafi et al., 2005; Rahman et al., 2005). The rhizobia protease was very stable in a broad $\mathrm{pH}$ range, maintaining over $78 \%$ of activity between $\mathrm{pH} 8.0$ and 11.0 (Fig. 3). The protease produced by strain R-986 retained only $53 \%$ of their original activity at $\mathrm{pH} 6.0$, while the enzymes from strain R-993 had a loss of 58\%. This suggested instability of these enzymes in an acid environment.

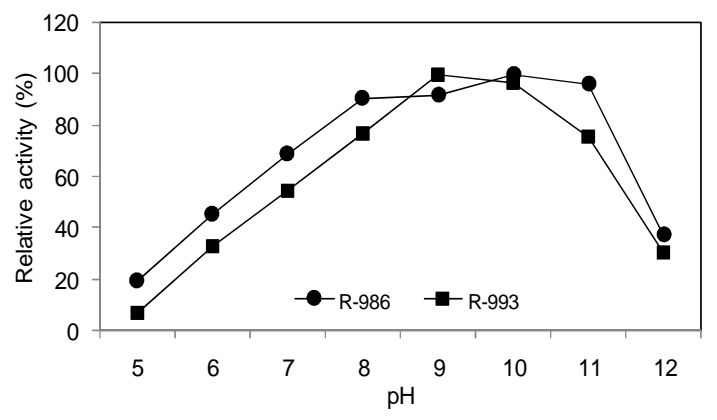

Figure 2 - Effect of $\mathrm{pH}$ on the proteolytic activities of the crude extracts from R-986 (13.2 $\mathrm{U} \mathrm{mL}^{-}$ $\left.{ }^{1}\right)$ and R-993 $\left(87.0 \mathrm{U} \mathrm{mL}^{-1}\right)$ strains. The enzyme activities of the strains are expressed as percentages of maximum.

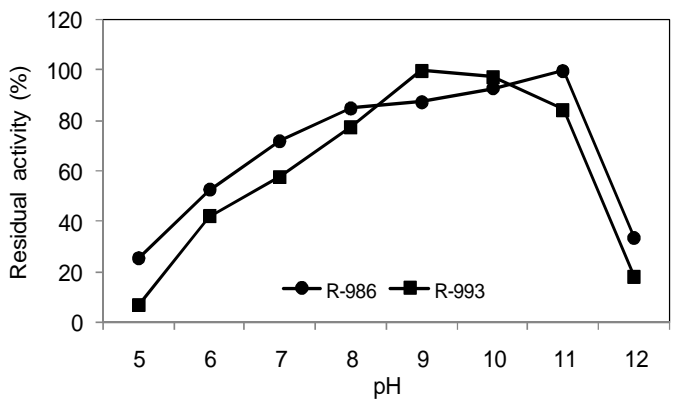

Figure 3 - Effect of $\mathrm{pH}$ on the stabilities (24 h) of the crude protease extracts from R-986 (12.8 U $\left.\mathrm{mL}^{-}\right)$and R-993 (86.2 $\left.\mathrm{U} \mathrm{mL}^{-1}\right)$ strains. The enzyme activities of the strains are expressed as percentages of maximum.

\section{Influence of temperature on enzyme activity and stability}

The optimum temperature for protease activity from strain R-986 was $35{ }^{\circ} \mathrm{C}$ and activity decreased gradually above this temperature (Fig. 4). The temperature range for optimum catalytic activity of numerous proteases was between 30 and $47^{\circ} \mathrm{C}$ (Schokker and van Boekel, 1997; Singh et al., 2001; Dutta and Banerjee, 2006; Genckal and Tari, 2006). At temperatures from 25 to $55^{\circ} \mathrm{C}$, significant increases in enzyme activity of strain R-993 were observed (Fig. 4). Above the optimum temperature of $55{ }^{\circ} \mathrm{C}$, protease activity decreased significantly. Similar results have been documented for other microbial proteases (Yang et al., 2000; Kumar, 2002; Moreira et al., 2003; Nascimento and Martins, 2004; Gupta et al., 2005).

The thermostability profile showed that at $2 \mathrm{~h}$, the crude protease extract from strain R-986 retained more than $90 \%$ of its catalytic activity at 25 to $35{ }^{\circ} \mathrm{C}$ (Fig. 5). However, above these temperatures, activity decreased significantly over the time. At $35{ }^{\circ} \mathrm{C}$, the crude enzyme produced by the strain R-993 was fully heat stable (Fig. 5). The crude protease extract of this strain also retained more than $80 \%$ of its maximum activity at $45^{\circ} \mathrm{C}$. Above $45{ }^{\circ} \mathrm{C}$, the activity declined sharply, 
possibly because of thermal inactivation. These crude protease extracts can be classified as mesophilic. In this study, the thermostabilities observed for both the rhizobia proteases were comparable to those mentioned for Bacillus proteases (Singh et al., 2001; Adinarayana et al., 2003; Genckal and Tari, 2006).

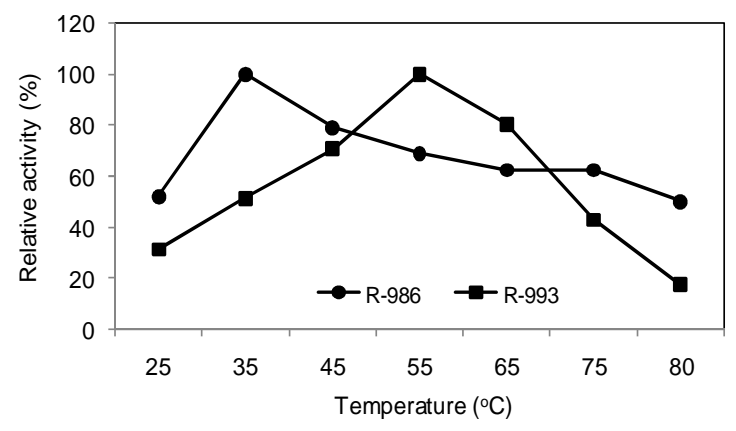

Figure 4 - Effect of temperature on the proteolytic activities of the crude extracts from R-986 $\left(12.2 \mathrm{U} \mathrm{mL}^{-1}\right)$ and R-993 $\left(85.4 \mathrm{U} \mathrm{mL}^{-1}\right)$ strains. The enzyme activities of the strains are expressed as percentages of maximum.

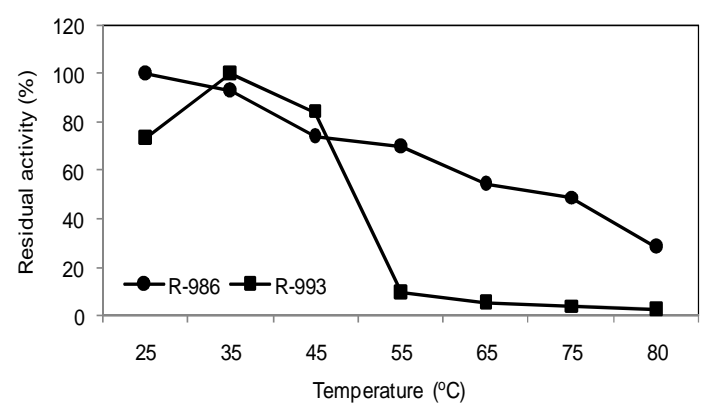

Figure 5 - Effect of temperature on the stabilities ( 2 h) of the crude protease extracts from R-986 $\left(12.0 \mathrm{U} \mathrm{mL}^{-1}\right)$ and R-993 $\left(84.8 \mathrm{U} \mathrm{mL}^{-1}\right)$ strains. The enzyme activities of the strains are expressed as percentages of maximum.

Influence of various metal ions on enzyme activity The influence of metal ions on enzyme activities ranged from a moderate inhibitory effect to a strong stimulatory effect (Table 1). Moderate inhibitions were observed in the presence of $\mathrm{Cu}^{2+}$ and $\mathrm{Zn}^{2+}$, which reduced the activity to between 15 and $27 \%$ of full activity. Heavy metal ions such as $\mathrm{Cu}^{2+}$ (Yang et al., 2000; Nascimento and Martins, 2004; Gupta et al., 2005) and $\mathrm{Zn}^{2+}$ (Nascimento and Martins, 2004; Gupta et al., 2005) have been reported to be inhibitory to alkaline proteases. $\mathrm{Na}^{+}$ $(5 \mathrm{mM}), \mathrm{Mg}^{2+}(5 \mathrm{mM})$ and $\mathrm{Mn}^{2+}(1$ and $5 \mathrm{mM})$ ions enhanced the proteolytic activities between 107 and $220 \%$. Of these metal ions, $\mathrm{Mn}^{2+}$ enhanced the enzyme activities by a minimum of $75 \%$ (Table 1). This showed that the proteolytic enzyme from these strains required $\mathrm{Mn}^{2+}$ for optimal activity. Strong stimulatory effects (69-
$300 \%)$ of $\mathrm{Mn}^{2+}$ ions on microbial proteases also have been observed by other authors (Yang et al., 2000; Suntornsuk et al., 2004; Sumantha et al. 2006).

In relation to $\mathrm{Hg}^{2+}$, present data contradict the results documented by other authors (Yang et al., 2000; Kumar, 2002; Nascimento and Martins, 2004; Yossan et al., 2006). On the other hand, $\mathrm{Hg}^{2+}$ ions had no significant inhibitory effect on protease activity of $B$. subtilis PE-11 (Adinarayana et al., 2003), A. parasiticus (Tunga et al., 2003) and Halogeometricum borinquense TSS101 (Vidyasagar et al., 2006). These results suggested that the effect of $\mathrm{Hg}^{2+}$ could vary among the microbial proteases, as observed for other heavy metal ions, such as $\mathrm{Co}^{2+}$ (Beg and Gupta, 2003; Karbalaei-Heidari et al., 2007), $\mathrm{Ni}^{2+}$ (Beg and 
Gupta, 2003; Yossan et al., 2006) and $\mathrm{Sr}^{2+}$ (Rahman et al., 2006).

\section{Influence of inhibitors on enzyme activity}

Proteases can be classified by their sensitivity to various inhibitors. The effect of a variety of protease inhibitors, such as $\beta$-mercaptoethanol, ethylene diamine tetraacetic acid (EDTA), $\mathrm{HgCl}_{2}$ and phenyl methyl sulphonyl fluoride (PMSF) on enzyme activity was investigated (Table 1). The crude enzymes secreted by the Rhizobium strain were slightly to moderately inhibited by $\beta$ mercaptoethanol (cysteine protease inhibitor), EDTA (metalloprotease inhibitor) and $\mathrm{HgCl}_{2}$ (cysteine protease inhibitor). The $\beta$ mercaptoethanol (10 and $100 \mathrm{mM}$ ) also caused a moderate inhibition (20-36\%) on the activity of the Bradyrhizobium strain (Table 1). In the presence of EDTA, there was up to $68 \%$ inhibition, which suggested the presence of metalloproteases in the crude enzyme extract of this strain. The PMSF caused strong inhibition (77-82\%) of enzyme activities of both rhizobia strains (Table 1). These results suggested that the enzyme secreted by strain INPA R-986 could belong to the class of serine proteases, whereas that produced by strain INPA R-993 was possibly a mixture of serine protease with metalloprotease. This type of inhibition profile also was reported for proteases from Pseudoperkinsus tapetis (Ordás et al., 2001), Vibrio fluvialis (Venugopal and Saramma, 2006), B. circulans (Jaswal and Kocher, 2007).

Table 1 - Effect of metal ions, inhibitors, and oxidizing and reducing agents on activity of crude extracellular proteases of two indigenous Central Amazonian rhizobia strains.

\begin{tabular}{|c|c|c|c|}
\hline $\begin{array}{l}\text { Ions, inhibitors and oxidizing } \\
\text { and reducing agents }\end{array}$ & $\begin{array}{c}\text { Concentration } \\
(\mathbf{m M})\end{array}$ & $\begin{array}{c}\text { Rhizobium strain } \\
\text { R-986 }(\%)\end{array}$ & $\begin{array}{c}\text { Bradyrhizobium strain } \\
\text { R-993 (\%) }\end{array}$ \\
\hline Control & 0 & 100 & 100 \\
\hline \multirow[t]{2}{*}{$\mathrm{K}^{+}(\mathrm{KCl})$} & 1 & 99 & 98 \\
\hline & 5 & 95 & 99 \\
\hline \multirow[t]{2}{*}{$\mathrm{Na}^{+}(\mathrm{NaCl})$} & 1 & 99 & 103 \\
\hline & 5 & 107 & 114 \\
\hline \multirow{2}{*}{$\mathrm{Ca}^{2+}\left(\mathrm{CaCl}_{2} \cdot 2 \mathrm{H}_{2} \mathrm{O}\right)$} & 1 & 94 & 99 \\
\hline & 5 & 105 & 97 \\
\hline \multirow[t]{2}{*}{$\mathrm{Hg}^{2+}(\mathrm{HgCl})$} & 1 & 106 & 105 \\
\hline & 5 & 94 & 97 \\
\hline \multirow[t]{2}{*}{$\mathrm{Mg}^{2+}\left(\mathrm{MgCl}_{2} \cdot 7 \mathrm{H}_{2} \mathrm{O}\right)$} & 1 & 114 & 107 \\
\hline & 5 & 110 & 115 \\
\hline \multirow[t]{2}{*}{$\mathrm{Mn}^{2+}\left(\mathrm{MnSO}_{4}\right)$} & 1 & 208 & 175 \\
\hline & 5 & 220 & 200 \\
\hline \multirow[t]{2}{*}{$\mathrm{Cu}^{2+}\left(\mathrm{CuSO}_{4} \cdot 5 \mathrm{H}_{2} \mathrm{O}\right)$} & 1 & 85 & 82 \\
\hline & 5 & 82 & 80 \\
\hline \multirow{2}{*}{$\mathrm{Zn}^{2+}\left(\mathrm{ZnSO}_{4} \cdot 7 \mathrm{H}_{2} \mathrm{O}\right)$} & 1 & 73 & 74 \\
\hline & 5 & 74 & 75 \\
\hline \multirow[t]{3}{*}{$\beta$-Mercaptoethanol } & 5 & 92 & 108 \\
\hline & 10 & 82 & 80 \\
\hline & 100 & 71 & 74 \\
\hline \multirow[t]{3}{*}{ EDTA } & 5 & 79 & 48 \\
\hline & 10 & 79 & 48 \\
\hline & 100 & 71 & 32 \\
\hline \multirow[t]{3}{*}{$\mathrm{HgCl}_{2}$} & 5 & 102 & 104 \\
\hline & 10 & 94 & 97 \\
\hline & 100 & 75 & 81 \\
\hline \multirow[t]{3}{*}{ PMSF } & 5 & 37 & 32 \\
\hline & 10 & 34 & 28 \\
\hline & 100 & 23 & 18 \\
\hline \multirow[t]{2}{*}{$\mathrm{H}_{2} \mathrm{O}_{2}$} & 5 & 87 & 115 \\
\hline & 10 & 87 & 100 \\
\hline \multirow[t]{2}{*}{$\beta$-Mercaptoethanol } & 5 & 92 & 108 \\
\hline & 10 & 82 & 80 \\
\hline
\end{tabular}

The enzyme activities of strains R-986 (12.4 $\left.\mathrm{U} \mathrm{mL}^{-1}\right)$ and R-993 $\left(84.5 \mathrm{U} \mathrm{mL}^{-1}\right)$ are expressed as percentages of the activity levels in the absence of metal ions, inhibitors, and oxidizing and reducing agents (control). 
Influence of oxidizing and reducing agents on enzyme activity

The crude protease extract secreted by INPA R986 was slightly inhibited by $\mathrm{H}_{2} \mathrm{O}_{2}(13 \%)$ and $\beta$ mercaptoethanol (8-18\%) (Table 1). At the concentration of $10 \mathrm{mM}$, the $\beta$-mercaptoethanol also caused a slight reduction (19\%) in the activity of INPA R-993. Slight inhibition by $\beta$ mercaptoethanol (Singh et al., 2001; Yang et al.,2000; Vidyasagar et al., 2006) and $\mathrm{H}_{2} \mathrm{O}_{2}$ (Oberoi et al., 2001; Genckal and Tari, 2006; Hadj-Ali et al., 2007) has been observed for other bacterial proteases.

Protease activity from strain R-993 was enhanced (15\%) in the presence of $5 \mathrm{mM} \mathrm{H}_{2} \mathrm{O}_{2}$. This result was similar to those of Johnvesly and Naik (2001), Beg and Gupta (2003), Joo et al. (2003) and Nilegaonkar et al. (2007), where serine proteases were stimulated by $\mathrm{H}_{2} \mathrm{O}_{2}$ (1 and $\left.5 \%\right)$. The tolerance to $\mathrm{H}_{2} \mathrm{O}_{2}$ is of great interest, especially in the detergent industry (Gupta et al., 2002; Maurer, 2004), in which this chemical agent is a fundamental component of many formulations.

\section{Influence of surfactants on enzyme activity}

Among the surfactants tested, only Tween- 80 showed a stronger inhibitory effect $(50-60 \%)$ on protease activity of the Bradyrhizobium strain (Table 2). In contrast, SDS (1\%) and Triton X-100 (1\%) enhanced the activity by 12 and $16 \%$, respectively. The crude protease extract from the Rhizobium strain was stable and retained $100 \%$ activity in the presence of these two surfactants. However, SDS and Triton X-100 at 2\% caused a moderate inhibition of 10 and $30 \%$, respectively (Table 2).

The influence of surfactants on protease activity is extremely variable in the literature. Olivera et al. (2006) observed inhibitory effects $(27 \%)$ of SDS $(1 \%)$ on protease activity from $B$. patagoniensis. In the presence of Triton X-100 (1\%), the study showed a stimulatory effect. At a concentration of $1 \%$, SDS and Tween- 80 caused strong inhibitory effects $(50 \%)$ on protease activity from Pseudomonas aeruginosa PD100 (Najafi et al., 2005). SDS (0.1\%) reduced by $39 \%$ the activity of the protease enzyme produced by $P$. aeruginosa PseA (Gupta et al., 2005). In the same study, Triton X-100 (0.1\%) and Tween-80 (0.1\%) showed stimulatory effects (6-12\%). Similarly, SDS $(0.1 \%)$ and Triton X-100 (0.2\%) increased by up to $22 \%$ protease activity from Streptomyces albidoflavus (Bressolier et al., 1999).

Table 2 - Effect of surfactants and organic solvents on activity of crude extracellular proteases of two indigenous Central Amazonian rhizobia strains.

\begin{tabular}{lccc}
\hline Surfactants and solvents & $\begin{array}{c}\text { Concentration } \\
(\boldsymbol{\%})\end{array}$ & $\begin{array}{c}\text { Rhizobium } \\
\text { strain R-986 }(\boldsymbol{\%})\end{array}$ & $\begin{array}{c}\text { Bradyrhizobium strain R- } \\
\mathbf{9 9 3}(\boldsymbol{\%})\end{array}$ \\
\hline Control & 0 & 100 & 100 \\
SDS & 1 & 100 & 112 \\
Triton X-100 & 2 & 90 & 99 \\
& 1 & 100 & 116 \\
Tween-80 & 2 & 70 & 108 \\
& 1 & 87 & 60 \\
Acetone & 2 & 79 & 50 \\
& 10 & 108 & 72 \\
n-Hexane & 20 & 103 & 64 \\
& 10 & 74 & 52 \\
Methanol & 20 & 68 & 44 \\
1-Propanol & 10 & 82 & 80 \\
Toluene & 20 & 53 & 32 \\
& 10 & 68 & 44 \\
\hline
\end{tabular}

The enzyme activities of strains R-986 (11.0 $\left.\mathrm{U} \mathrm{mL}^{-1}\right)$ and R-993 $\left(81.4 \mathrm{U} \mathrm{mL}^{-1}\right)$ are expressed as percentages of the activity levels in the absence of surfactants and organic solvents (control). 
Influence of organic solvents on enzyme activity The rhizobia proteases had the ability to act in the presence of different concentrations of solvents in the reaction system (Table 2). Protease activity from Rhizobium sp. was enhanced by up to $8 \%$ in the presence of acetone. Similar observations were reported for proteases isolated from Pseudomonas aeruginosa strains (Ogino et al., 1999; Gupta et al., 2005). In contrast, the addition of acetone caused a decrease of $28-36 \%$ in the activity of the Bradyrhizobium strain. Similar reductions of protease activity have been reported for $P$. aeruginosa PD100 (Najafi et al., 2005).

At a concentration of $20 \%$, n-hexane, methanol, 1propanol and toluene caused decreases of 32 to $76 \%$ on proteolytic activities from the rhizobia strains. However, at a concentration of $10 \%$, more than $40 \%$ of full activity was observed in the presence of n-hexane, methanol and 1-propanol (Table 2). According to Najafi et al. (2005), this capability could be due to disulfide bonds. There are a number of reports on the importance of disulfide bonds for the stability of proteins in the presence of solvents (Ogino et al., 2001; Najafi et al., 2005; Rahman et al., 2005). The proteases studied here could be very useful for fermentation and other reactions in the presence of solvents. One of the most important advantages of this property is to reduce or abolish the microbial contamination during the degradation reactions (Najafi et al., 2005). Enzyme-catalysed reactions in organic solvents have found numerous applications, some of which have been commercialized (Klibanov, 2001).

\section{CONCLUSIONS}

Based on the biochemical properties evaluated in this study, the crude rhizobia protease extracts appeared to be useful sources of enzymes for the detergent formulations. Furthermore, they have the ability to act in the presence of several organic solvents and could, therefore, be used for the reactions in media containing organic solvents.

\section{ACKNOWLEDGMENTS}

The financial support provided by the Fundação de Amparo à Pesquisa do Estado do Amazonas (Fapeam Process 1437/2006) is gratefully acknowledged. The authors also thank Dr. C.R. Clement, INPA, for reviewing the English. L.A.O. is a CNPq fellow.

\section{RESUMO}

Duas estirpes de rizóbia isoladas de solos de várzea da Amazônia Central produziram grandes quantidades de proteases alcalinas extracelulares, usando fontes baratas de carbono e nitrogênio. Os extratos brutos de proteases foram ativos em $\mathrm{pH}$ 9,0-11,0. As temperaturas ótimas foram de $35^{\circ} \mathrm{C}$ para a enzima do Rhizobium R-986 e de $55{ }^{\circ} \mathrm{C}$ para a do Bradyrhizobium R-993. As atividades proteolíticas aumentaram na presença de $5 \mathrm{mM}$ dos íons $\mathrm{Na}^{+}, \mathrm{Ca}^{2+}, \mathrm{Mg}^{2+}$ e $\mathrm{Mn}^{2+}$. As proteases secretadas pelos rizóbios foram fortemente inibidas por PMSF, um inibidor de serina protease. As enzimas foram ativas na presença de surfactantes (SDS e Triton X-100), e estáveis na presença de agentes oxidantes $\left(\mathrm{H}_{2} \mathrm{O}_{2}\right)$ e redutores ( $\beta$-mercaptoetanol) e solventes orgânicos (acetona, hexano, metanol, 1-propanol e tolueno).

\section{REFERENCES}

Adinarayana, K.; Ellaiah, P. and Prasad, D.S. (2003), Purification and Partial Characterization of Thermostable Serine Alkaline Protease from a Newly Isolated Bacillus subtilis PE-11. AAPS PharmSciTech., 4, 1-9.

Agrawal, D.; Patidar, P.; Banerjee, T. and Patil, S. (2004), Production of alkaline protease by Penicillium sp. under SSF conditions and its application to soy protein hydrolysis. Process Biochem., 39, 977-981.

Al-Shehri, A.; Mostafa, M. and Yasser, S. (2004), Production and some properties of protease produced by Bacillus licheniformis isolated from Tihamet Asser, Saudi Arabia. Pak. J. Biol. Sci., 7, 1631-1635.

Azeredo, L.A.I.; Freire, D.M.G.; Soares, R.M.A.; Leite, S.G.L. and Coelho, R.R.R. (2004), Production and partial characterization of thermophilic proteases from Streptomyces sp. isolated from Brazilian cerrado soil. Enzyme Microb. Technol., 34, 354-358.

Beg, Q.K. and Gupta, R. (2003), Purification and characterization of an oxidation-stable, thioldependent serine alkaline protease from Bacillus mojavensis. Enzyme Microb. Technol., 32, 294-304.

Bressollier, P.; Letoumeau, F.; Urdaci, M. and Verneuil, B. (1999). Purification and characterization of a keratinolytic serine proteinase from Streptomyces 
albidoflavus. Appl. Environ. Microbiol., 65, 25702576.

Durham, D.R.; Stewart, D.B. and Stelwag, E.G. (1987), Novel alkaline and heat stable proteases from alkalophilic Bacillus sp. Strain GX6638. J. Bacteriol., 169, 2762-2768.

Dutta, J.R. and Banerjee, R. (2006), Isolation and characterization of a newly isolated Pseudomonas mutant for protease production. Braz. arch. biol. technol., 49, 33-47.

Elibol, M. and Moreira, A.R. (2005), Optimizing some factors affecting alkaline protease production by a marine bacterium Teredinobacter turnirae under solid substrate fermentation. Process Biochem., 40, 1951-1956.

Genckal, H. and Tari, C. (2006), Alkaline protease production from alkalophilic Bacillus sp. isolated from natural habitats. Enzyme Microb. Technol., 39, 703-710.

Gornall, A.G.; Bardawill, C.J. and David, MM. (1949), Determination of serum proteins by mean of biuret reaction. J. Biol. Chem., 177, 751-756.

Gupta, A.; Roy, I.; Khare, S.K. and Gupta, M.N. (2005), Purification and characterization of a solven stable protease from Pseudomonas aeruginosa PseA. J. Chromatogr. A. 1069, 155-161.

Gupta, R.; Beg, Q.K. and Lorenz, P. (2002). Bacterial alkaline proteases: molecular approaches and industrial application. Appl. Microbiol. Biotechnol., 59, 15-32.

Hadj-Ali, N.E.; Agrebi, R.; Ghobel-Frikha, B.; SellamiKamoun, A.; Kanoun, S. and Nasri, M. (2007), Biochemical and molecular characterization of a detergent stable alkaline serine-protease from a newly isolated Bacillus licheniformis NH1. Enzyme Microb. Technol., 40, 515-523.

Jaswal, R.K.; Kocher, G.S. (2007), Partial characterization of a crude alkaline protease from Bacillus circulans and its detergent compatibility. Internet J. Microbiol., 4, 1-7.

Johnvesly, B. and Naik, G.R. (2001), Studies on production of thermostable alkaline protease from thermophilic and alkalophilic Bacillus sp. JB-99 in a chemically defined medium. Process Biochem., 37, 139-144.

Joo, H.-S.; Kumar, C.G.; Park, G.-C.; Paik, R.S. and Chang, C.-S. (2003), Oxidant and SDS-stable alkaline protease from Bacillus clausii I-52: production and some properties. J. Appl. Microbiol. 95, 267-272.

Karbalaei-Heidari, H.R.; Ziaee, A.A.; Schaller, J. and Amoozegar, M.A. (2007). Purification and characterization of an extracellular haloalkaline protease produced by the moderaly halophilic bacterium, Salinivibrio sp. strain AF-2004. Enzyme Microb. Technol., 40, 266-272.
Klibanov, A.M. (2001). Improving enzymes by using them in organic solvents. Nature, 409, 241-246.

Kumar, C.G. (2002), Purification and characterization of a thermostable alkaline protease from alkalophilic Bacillus pumilus. Lett. Appl. Microbiol., 34, 13-17.

Maurer, K.H. (2004), Detergent proteases. Curr. Opin. Biotechnol., 15, 330-334.

Moreira, K.A.; Porto, T.S.; Teixeira, M.F.S. Porto, A.L.F. and Lima-Filho, J.L. (2003), New alkaline protease from Nocardiopsis sp.: partial purification and characterization. Process Biochem., 39, 67-79.

Najafi, M.F.; Deobagkar, D. and Deobagkar, D. (2005). Potential application of protease isolated from Pseudomonas aeruginosa PD100. Electron. J. Biotechnol., 8, 197-203.

Nascimento, W.C.A. and Martins, M.L.L. (2004), Production and properties of an extracellular protease from thermophilic Bacillus sp. Braz. J. Microbiol., 35, 91-96.

Nilegaonkar, S.S.; Zambare, V.P.; Kanekar, P.P.; Dhakephalkar, P.K. and Sarnaik, S.S. (2007), Production and partial characterization of hehairing protease from Bacillus cereus MCM B-326. Biores. Technol., 98, 1238-1245.

Oberoi, R.; Beg, Q.K.; Puri, S.; Saxena, R.K. and Gupta, R. (2001), Characterization and wash performance analysis of an SDS-stable alkaline protease from a Bacillus sp. World J. Microbiol. Biotechnol., 17, 493-497.

Ogino, H.; Yamada, M.; Watanabe, F.; Ichinose, H.; Yasuda, M. and Ishikawa, H. (1999), Peptide synthesis catalyzed by organic solvent-stable protease from Pseudomonas aeruginosa PST-01 in monophasic aqueous-organic solvent systems. $J$. Biosci. Bioeng. 88, 513-518.

Ogino, H.; Uchiho, T.; Yokoo, J.; Kobayashi, R.; Ichise, R. and Ishikawa, H. (2001), Role of intermolecular disulfide bonds of the organic solventstable Pseudomonas aeruginosa PST-01 protease in its organic solvent stability. Appl. Environ. Microbiol., 67, 942-947.

Olajuyigbe, F.M. and Ajele, J.O. (2005), Production dynamics of extracellular protease from Bacillus species. Afr. J. Biotechnol., 4, 776-779.

Olivera, N.; Sequeiros, C.; Siñeriz, F. and Breccia, J.D. (2006), Characterization of alkaline proteases from a novel alkali-tolerant bacterium Bacillus patagoniensis. World J. Microbiol. Biotechnol., 22, 737-743.

Oliveira, A.N. (2006), Caracterização de amilases e proteases em isolados de rizóbia nativos da Amazônia Central. Doctoral Thesis, Universidade Federal do Amazonas, Amazonas, Brasil. 
Oliveira, A.N.; Oliveira, L.A, Andrade, J.S.; ChagasJúnior, A.F. (2006a), Enzimas hidrolíticas extracelulares de isolados de rizóbia nativos da Amazônia Central, Amazonas, Brasil. Ciênc. Tecnol. Aliment., 26, 853-860.

Oliveira, A.N.; Oliveira, L.A, Andrade, J.S.; ChagasJúnior, A.F. (2006b), Atividade enzimática de isolados de rizóbia nativos da Amazônia Central crescendo em diferentes níveis de acidez. Ciênc. Tecnol. Aliment., 25, 204-210.

Ordás, M.C.; Novoa, B.; Faisal, M.; McLaughlin, S.; Figueras, A. 2001, Proteolytic activity of cultured Pseudoperkinsus tapetis extracellular products, Comp. Biochem. Physiol., 130, 199-206.

Patel, R.; Dodia, M. and Singh, S.P. (2005), Extracellular alkaline protease from a newly isolated haloalkaliphilic Bacillus sp.: Production and optimization. Process Biochem., 40, 3569-3575.

Rahman, R.N.Z.R.A.; Geok, L.P.; Basri, M. and Salleh, A.B. (2005), An organic solvent-tolerant protease from Pseudomonas aeruginosa strain K: Nutritional factors affecting protease production. Enzyme Microb. Technol., 36, 749-757.

Rahman, R.N.Z.R.A.; Geok, L.P.; Basri, M. and Salleh, A.B. (2006), An organic solvent-stable alkaline protease from Pseudomonas aeruginosa strain K: Enzyme purification and characterization. Enzyme Microb. Technol., 39, 1484-1491.

Sánchez-Porro, C.; Mellado, E.; Bertoldo, C.; Antranikian, G. and Ventosa, A. (2003), Screening and characterization of the protease $\mathrm{CP} 1$ produced by the moderately halophilic bacterium Pseudoalteromonas sp. strain CP76. Extremophiles, 7, 221-228.

Schokker, E.P. and van Boekel, M.A.J.S. (1997), Production, purification and partial characterization of extracellular proteinase from Pseudomonas fluorescens 22 F. Int. Dairy J. 7, 265-271.

Seeta Laxman, R.; Sonawane, A.P.; More, S.V.; Rao, B.S.; Rele, M.V.; Jogdand, V.V.; Deshpande, V. and Rao, M.B. (2005), Optimization and scale up of production of alkaline protease from Conidiobolus coronatus. Process Biochem., 40, 3152-3158.

Singh, J.; Batra, N. and Sobti, R.C. (2001), Serine alkaline protease from a newly isolated Bacillus sp. SSR1. Process Biochem., 36, 781-785.
Sumantha, A.; Deepa, P.; Sandhya, C.; Szakacs, G.; Soccol, C.R.; Pandey, A. (2006), Rice bran as a substrate for proteolytic enzyme production. Braz. arch. biol. technol., 49, 843-851.

Suntornsuk, W.; Tongjun, J.; Onnim, P.; Oyama, H.; Ratanakanokchai, K.; Kusamran, T.; Oda, K. (2004), Purification and characterisation of keratinase from a thermotolerant feather-degrading bacterium. Disponível em: http://www.thaiscience.info/Article. Acesso em 13 ago. 2008.

Tunga, R.; Shrivastava, B. and Banerjee, R. (2003), Purification and characterization of a protease from solid state cultures of Aspergillus parasiticus. Process Biochem., 38, 1553-1558.

Venugopal, M and Saramma, A.V. (2006), Characterization of alkaline protease from Vibrio fluvialis strain VM10 isolated from a mangrove sediment sample and its application as a laundry detergent additive. Process Biochem., 41, 1239-1243.

Vidyasagar, M.; Prakash, S.; Litshfield, C. and Sreeramulu, K. (2006), Purification and characterization of a thermostable, haloalkaliphilic extracellular serine protease from the halophilic archaeon Halogeometricum borinquense strain TSS101. Archaea, 2, 51-57.

Vincent, J.M. (1970), A manual for the practical study of root-nodules bacteria. Blackwell Science Publication, Oxford, UK, pp. 164.

Yang, J.K.; Shih, I.L.; Tzeng, Y.M. and Wang, S.L. (2000), Production and purification of protease from Bacillus subtilis that can deproteinize crustacean wastes. Enzyme Microb. Technol., 26, 406-413.

Yossan, S.; Reungsang, A. and Yasuda, M. (2006), Purification and characterization of alkaline protease from Bacillus megaterium isolated from thai fish sauce fermentation process. Sci. Asia, 32, 377-383.

Received: January 17, 2008; Revised: June 17, 2008; Accepted: April 13, 2010. 